\title{
The Financial Impact of High-Performance Work Practices: The Moderating Effects of Labor Market Flexibility and Labor Market Efficiency
}

\author{
Clyde Eiríkur Hull \\ Saunders College of Business, Rochester Institute of Technology \\ E-Mail: chull@saunders.rit.edu \\ Sandra Rothenberg \\ Saunders College of Business, Rochester Institute of Technology \\ E-Mail: srothenberg@saunders.rit.edu \\ Sebastian Vogt \\ Deloitte Switzerland \\ E-Mail: Vogt-Sebastian@outlook.de
}

\begin{abstract}
High-performance work practices (HPWP) have been found to increase financial performance. Institutional theory suggests that this effect may be moderated by labor market institutions, such as labor market flexibility and labor market efficiency. We explore this relationship using a combined data set comprised of data on HPWP from ASSET4, financial and other company-level data from the Worldscope Database, and national institutional context data from the World Economic Forum's Global Competitiveness Report. With an international sample of roughly 20,000 archival firmyear observations across a seven-year period, we use pooled OLS regression models with robust standard errors, clustered at the firm level. We find support for all predicted relationships except for a direct relationship between labor market flexibility and performance: Strong formal institutional pressure (low labor market flexibility) increases the positive financial impact of HPWP. Strong informal institutional pressure (high labor market efficiency) affects the financial performance of businesses directly and positively, and also indirectly by increasing the positive effect of HPWP on financial performance. We conclude that companies seeking the most financially-rewarding approach to human resource management (HRM) should engage in HPWP, encourage the local population to
\end{abstract}


expect and value such practices (e.g., by promoting women's rights), and, counterintuitively, encourage more government regulation of business around HRM practices.

Keywords: High-performance work practices, High-performance work systems, Institutional theory, Labor market, Performance, International

\section{INTRODUCTION}

High-performance work practices (HPWP) are practices that engage and train employees strategically and hire and reward them based on merit rather than their sex, connections, etc. (Sun et al., 2007). Past research has shown that HPWP positively contributes to various aspects of social and financial performance (Combs et al., 2006; Rothenberg et al., 2017; Storey et al., 2019; Tang et al., 2012; Zhang et al., 2014). This impact, at least for financial performance, is significant and positive without regard for context (Combs et al., 2006; Storey et al., 2019; Zhang et al., 2014). There is much less research, however, on the external factors that impact this relationship. Theory and empirical evidence suggest that, given different nations with different institutional structures, financial performance will be affected differently by antecedents such as HPWP (Chacar, et al., 2010; Huselid, 1995; Paauwe, 2009; Paauwe \& Boon, 2018; Witt \& Jackson, 2016). Many studies, directly and indirectly, support the notion that national differences, for example, impact the effectiveness of HRM practices (Caligiuri, 2014; Fey et al., 2009). The emphasis here is typically on informal institutions, but formal institutional pressures, including government policies that focus on employer-labor relations, are also likely to impact how a company's approach to HRM affects performance (Bauer et al., 2018).

According to institutional theory, informal institutional pressures (i.e., cultural norms and expectations) and formal institutional pressures (i.e., legal and regulatory requirements) in different countries affect the results of various choices and actions (Caligiuri, 2014; Minbaeva et al., 2014; Scott, 1995; Weng \& Peng, 2018). Thus, we should expect the relationship between HPWP and financial performance to be stronger in some countries than in others. Some formal and informal structures in one country might magnify the benefits of HPWP, while others might diminish them.

In the context of labor-related practices, institutional theory suggests that labor-related institutional factors will impact the relationship between company actions, such as engaging in HPWP, and financial performance (Caligiuri, 2014; Minbaeva et al., 2014; Weng \& Peng, 2018). Most work in this area largely considers the impact of institutional pressures on choice of activity, rather than on the effects of a choice such as that to engage 
in HPWP. Our study responds to recent calls for additional research on the impact of laborrelated institutional factors on financial performance and on the HRM-financial performance relationship (Caligiuri, 2014; Minbaeva et al., 2014; Weng \& Peng, 2018).

Little is known about institutional factors' impact on how much firms benefit financially from high-performance work practices (HPWP) such as job security, training or talent management, appraisal and rewards systems, and beneficial employee relations (Caligiuri, 2014; Maamari \& Alameh, 2016; Minbaeva et al., 2014; Sun et al., 2007). To fill this gap in the literature, we look at the differential impact of two types of institutional pressure - formal and informal (c.f., Mallon \& Fainshmidt, 2017; Williamson, 2009).

Thus, this paper makes contributions on a number of fronts. It answers the call for research on the impacts of institutional pressures on the HPWP-performance relation. It takes a more detailed look at this relationship by separating form and informal institutional pressures. In so doing, it moves the discussion beyond whether there is a positive relationship, to the institutional conditions under which the benefits of HPWP can be maximized. This paper also adds to the emerging institutional theory literature that considers the differential impacts of formal and informal institutional pressures on firm performance (e.g., Mallon \& Fainshmidt, 2017).

\section{LITERATURE REVIEW AND HYPOTHESIS DEVELOPMENT}

\section{High-Performance Work Practices}

Figure 1 outlines our hypothesis, as detailed below. HPWP can enhance and support other firm capabilities by increasing employees' ability, loyalty and motivation to help the company achieve its ends (Costa et al., 2015; Maamari \& Alameh, 2016; Rothenberg et al., 2017). The resource-based view (RBV) is the dominant theory used to support the value of HPWP (Paauwe \& Boselie, 2006). RBV suggests that combinations or bundles of complementary capabilities are particularly effective at driving competitive advantage (Barney, 1986, 1991, 2001) and that stakeholders, such as employees, are an important factor in this process (Barney, 2018). In this case, the bundle is what we call highperformance work practices (HPWP), a bundle of diverse but complementary capabilities, such as worker participation, effective reward systems, and employee training and talent management (Maamari \& Alameh, 2016; Rothenberg et al., 2017; Sun et al., 2007). HPWP creates and strengthens the other capabilities of the firm (Combs et al., 2006; Paauwe, 2009; Paauwe \& Boon, 2018).

Effective human resource management is the most logical capability to use to develop the human capital resources of a firm and use them to build core competencies essential to the firm's strategy (Paauwe, 2009; Paauwe \& Boon, 2018; Storey, 2019). Developing 
human resources can increase a firm's ability to adapt to external change by facilitating the accumulation of organizational knowledge and increasing creativity and risk-taking (Williams \& Lee, 2016), which lead to increased financial and social performance (Combs et al., 2006; Rothenberg et al., 2017). Thus, HPWP creates and enables other capabilities, and so create core competencies that contribute to financial performance.

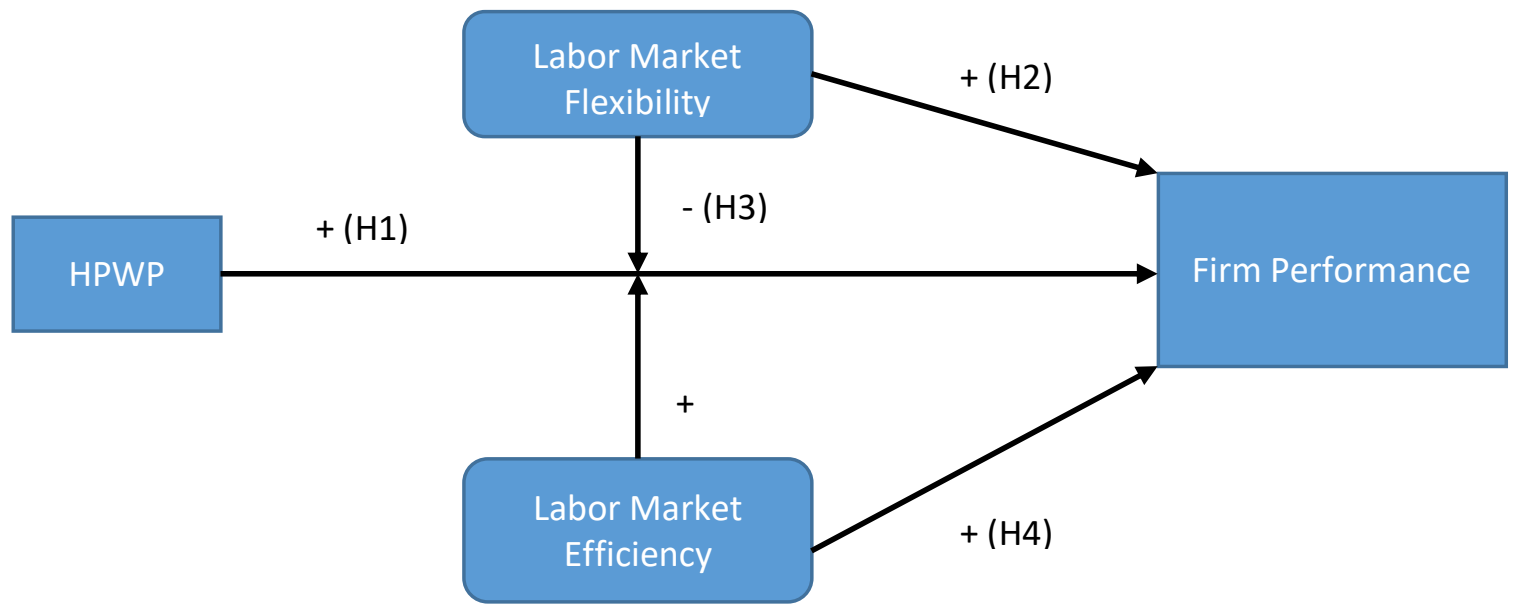

Figure 1. Diagram Showing Hypothesized Relationships

Practices that engage the workforce lead to a more successful organization (Schneider et al., 2018). Another way HPWP can impact firm performance is by differentiating the firm to internal and external stakeholders (Schneider et al., 2018). Externally, they can send a credible signal to stakeholders that the firm is socially responsible, which can then result in increased customer loyalty, increased ability to recruit and retain higher quality employees, and improved financial performance (Guerci et al., 2019; Schneider et al., 2018; Tang et al., 2012; Yang et al., 2019). Internally, employee perceptions of a firm's commitment to its employees lead to increased organizational identification and harder work on behalf of the organization's goals (Cole et al., 2010; El Akremi et al., 2018; Schneider et al., 2018).

While there is disagreement regarding the specific practices to be included in the configuration of HPWP (Obeidat et al., 2016), there are three main areas of HPWP: (1) people-flow and skills, such as job security and training, (2) appraisal and rewards, and (3) employment relations, such as worker participation and job design (Sun et al., 2007). These three areas of the HRM system support one another to create a high-performance work system - meaning that a complete "bundle" of practices covering these three areas (Obeidat et al., 2016) - is needed to reap the full benefit (Asmawi \& Chew, 2016; Combs et al., 
2006). HPWP help companies identify and train the right employees (enabling greater diversity through a stronger focus on ability), retain good employees, and assure continued investment in and engagement of employees (Schneider et al., 2018; Sun et al., 2007). The bundling of the knowledge, skills, and abilities of individual employees with HPWP creates valuable, rare, costly to imitate and non-substitutable human capital, a core competency that leads to increased performance (Combs et al., 2006; Obeidat et al., 2016; Schneider et al., 2018). Thus,

Hypothesis 1: High-performance work practices are positively associated with firm performance.

\section{Institutional Differences}

Institutional context plays an important role in evaluating strategic options and choosing a firm's direction (Bauer et al., 2018; Weng \& Peng, 2018; Witt \& Jackson, 2016; Wood \& Brewster, 2016). Institutional theory focuses on how institutional pressures affect organizational behavior (Ioannou \& Serafeim, 2012; Mallon \& Fainshmidt, 2017; Peng, 2014). This perspective suggests that institutional differences between different nations can have a major impact on how firms behave given the same specific circumstances and capabilities, as well as the ability of a firm to extract value from a given behavior (Chacar et al., 2010; Tang \& Hull, 2012; Weng \& Peng, 2018; Witt \& Jackson, 2016; Wood \& Brewster, 2016). Thus, understanding the interactions among organizations and national institutions is essential to understanding any sort of strategic behavior, including the sort of strategic behavior that involves HRM (Bauer et al., 2018; Peng, 2003, 2014; Paauwe \& Boselie, 2006).

Past research has found that institutional factors affect multinational enterprises' HRM practices in different nations (Bauer et al., 2018; Williamson, 2009). While institutional context can influence behavior, it can also influence the degree to which behavior contributes to financial performance (Bauer et al., 2018; Caligiuri, 2014; Minbaeva et al., 2014; Paauwe, 2009, Paauwe \& Boon, 2018). In particular, informal and formal institutional differences in labor markets and practices will be critical both to what a company is allowed to do and how it will be perceived for what it does, thus impacting two major mechanisms by which HRM impacts performance (Bauer et al., 2018; Sondermann, 2018; Weng \& Peng, 2018).

It is important to note that there is considerable disagreement as to how to measure formal and informal institutional pressures (Wood \& Brewster, 2016). As one example, nations can be categorized as liberal or coordinated market economies according to 
whether they practice civil or common law (Witt \& Jackson, 2016). Wood \& Brewster (2016), on the other hand, provide an excellent discussion of why this is not an appropriate method. Given this disagreement, one approach to measuring institutional pressures is to focus on relevant institutional pressures specific to the nation, rather than on national traits believed to affect these institutions (Wood \& Brewster, 2016).

We follow this logic in considering both informal and formal aspects of the institutional environment (Mallon \& Fainshmidt, 2017; Williamson, 2009). Formal aspects of the institutional environment are codified in rules, policies, and laws. Informal aspects are also constraints on behavior, but ones that are embedded in the customs, norms, and traditions of the country in question. Thus, in the context of labor markets, laws and regulatory policies regarding labor would be formal institutions, and less codified customs, norms and traditions would provide informal institutional pressure (Williamson, 2009). Labor market flexibility is a measure of how much latitude companies have in a particular country's labor market. This is a formal institutional pressure because it is codified in law. Labor market efficiency is a measure of the extent to which firms within a country provide employees with merit-based incentives or rewards for their productivity. It is reflective of the informal institutional environment since it measures the degree to which firms in a country undertake, and are expected to undertake, efforts to promote meritocracy by providing employees with strong incentives or rewards for their productivity. Examining the effects of both as moderating variables in a single study is an effective and recommended practice (c.f., Bauer et al., 2018). Both concepts are explained in greater detail below.

\section{Labor market flexibility}

The term "labor market flexibility" is linked to labor market regulations and formal institutional arrangements that, by a complex web of incentives and disincentives, govern relationships between employees and firms (Bauer et al., 2018; Sondermann, 2018). These rules and regulations govern, for example, unfair dismissals, compulsory severance packages, restrictions on corporate downsizing, minimum notice periods, and terms of work (e.g., the number of working hours). Countries with a high level of labor market flexibility have fewer labor regulations, and thus give firms more freedom in hiring and firing practices, wage determination, and establishment of work hours. Tax structures in these countries do not reduce incentives to work, giving employees a stronger financial incentive to stay on the job. On the other hand, a labor market with low flexibility has strong regulations regarding hiring and firing, making it expensive to fire people, a strong degree of labor coordination in the bargaining process, and a taxation system that reduces 
incentives to work. Companies in labor markets with high flexibility can choose to use HPWP, or not. Should they choose to use HPWP, they have considerable freedom as to exactly how. Companies in labor markets with low flexibility may be required to use specific HPWP, with little latitude as to specifics. It seems reasonable to expect that, in general, greater latitude to choose their own course will result in lower costs and higher financial performance, and that this greater freedom might apply in the specific context of labor markets.

In countries with more flexible labor markets, firms can more easily reallocate their labor than can firms in countries with more rigid labor markets (Bauer et al., 2018; Chacar et al., 2010). In nations with low flexibility, companies are monitored more closely to ensure they do the right thing, which often involves a comprehensive set of labor market regulations that are typically put in place to protect the labor force from arbitrary, unfair or discriminatory actions on the part of employers (Bauer et al., 2018; Sondermann, 2018). But, being monitored and controlled means that the company may not be able to pursue its goals as efficiently or as desired (Graafland, 2019; Sondermann, 2018; Weng \& Peng, 2018). Hence, being monitored and controlled may raise the effective cost of employing workers or of adjusting levels of employment over time (Sondermann, 2018; Weng \& Peng, 2018). This is consistent with the general concept of free-market enterprise that companies will perform best when unconstrained. Thus:

Hypothesis 2: Labor market flexibility is positively associated with firm performance.

\section{Labor market flexibility and HPWP}

There are a number of reasons why one might expect that labor market flexibility would enhance the positive impact of HPWP on performance. Some have argued that when operating in contexts with institutional voids corporate social responsibility (CSR) (including labor practices), can help performance by reducing transaction costs and improving access to resources (Ghoul et al., 2017). Others have also suggested that in contexts with weak formal institutions the economic benefits of corporate reputation might also be higher; this argument, however, has recently been challenged theoretically and the empirical support varies across different aspects of these formal institutional pressures (Luxmore et al., 2018; Swoboda et al., 2016).

Of critical importance in the area of HPWP in particular, however, is that highperformance practices fit together as a bundle or system (Asmawi \& Chew, 2016; Combs et al., 2006) and, in combination, have the effect that they do. Past research has shown that institutional context can affect the variety of HPWP adopted by firms in a particular 
country. Gilman \& Raby (2013), for example, found that a wider variety of HPWP bundles were adopted in small and medium-sized companies in the United Kingdom (UK), as compared to France, and point in part to the lower levels of labor regulation in the UK to explain this difference. In areas of low labor market flexibility, it is likely that formal institutional pressures help increase the likelihood that firms adopt "bundles" of work systems, while low levels of formal institutional pressure cause firms to adopt a more adhoc adoption of HPWP. Additionally, with a more comprehensive set of HPWP mandated by law, it may free up managers' finite attention so that they can focus on other issues where their decisions have more potential benefits and less potential risk for their firms (c.f., Simon, 2013; Williamson, 2009). Thus, we can expect HPWP to have a stronger positive impact on firm performance when labor market flexibility is low.

Hypothesis 3: HPWP is more positively associated with firm performance in settings of low labor market flexibility than in settings of high labor market flexibility.

\section{Labor market efficiency}

Arguably, firms have a high degree of latitude to implement various bundles of HPWPs relating to selection, development, involvement, rewards and relations that may impact employee motivation and performance without in any way falling foul of what is formally institutionally mandated. This does not mean that they are free of institutional pressure in these matters. Customer groups or competitors, for example, may be able to push a company to adopt more socially responsible practices (Helmig et al., 2016). While formal laws, rules, and regulations are covered by labor market flexibility, labor market efficiency captures the informal institutional pressures that may further limit the HRM options for a firm (Bauer et al., 2018; Mohaghar et al., 2018). Labor market efficiency describes the degree to which firms in a country undertake - and are expected to undertake - efforts to promote meritocracy by providing employees with strong incentives or rewards for their productivity. Countries with highly labor market efficiency provide an informal institutional context in which pay is strongly related to employees' productivity, where merit and qualification play an important role in the assignment of professional management positions, and where a higher proportion of women participate in the labor force (Bauer et al., 2018; Mohaghar et al., 2018). These countries provide many opportunities for talented people. In contrast, countries with a low level of labor market efficiency do not have strong incentive-based compensation systems and have a relatively smaller percentage of women in the labor force. Professional management positions are often assigned based on family ties instead of qualifications and merit. These countries 
may suffer a brain drain of talented people to other countries and a higher proportion of incompetence among those who remain. Thus, an institutional setting that allows the labor market efficiency should bolster financial performance. We predict:

Hypothesis 4: Labor market efficiency is positively associated with firm performance.

\section{Labor market efficiency and HPWP}

HPWP includes a variety of practices, such as training and development, focusing on employee health safety and employment quality, taking advantage of opportunities for increased diversity, and protecting human rights (Sun et al., 2007; Schneider et al., 2018). These practices overlap with, and would be enhanced by the informal institutional pressures included in labor market efficiency, such as policies and practices that allow for recruiting the best available talent without sexist, racist, or other bias, and then training and encouraging those employees to be capable and motivated to do the best job possible. Additionally, the informal institutional context can impact the degree to which corporate social responsibility is valued (Sondermann, 2018). It is not unreasonable to expect that HPWP will be rewarded more in a culture that values HPWP than in one that does not. Thus, we predict that HPWP will be most profitable under conditions of high levels of labor market efficiency.

Hypothesis 5: HPWP is more positively associated with firm performance in settings of high levels of labor market efficiency.

\section{METHODOLOGY}

\section{Sample Selection and Data Collection}

Our data include all firms for which complete data could be found in the several databases we used, yielding roughly 20,000 firm-year observations across a seven-year period from 2007 to 2013. As shown in Table 1, we used several data sets in this analysis. Our primary data source is ASSET4 from Thomson Reuters Environmental Social and Governance (ESG) Research Data, which is one of the major ESG rating agencies. 
Table 1. Databases Used for Each Variable in the Analysis

\begin{tabular}{|c|c|c|c|}
\hline Dataset & Publisher & Data Level & Variables \\
\hline ASSET4 & $\begin{array}{l}\text { Thomson } \\
\text { Reuters } \\
\text { Environmental } \\
\text { Social and } \\
\text { Governance } \\
\text { (ESG) } \\
\text { Research Data }\end{array}$ & $\begin{array}{l}\text { Company level } \\
\text { social } \\
\text { performance } \\
\text { data }\end{array}$ & $\begin{array}{l}\text { HPWP score (using a weighted } \\
\text { average of training and } \\
\text { development, health and safety, } \\
\text { employment quality, diversity and } \\
\text { opportunity, and human rights) }\end{array}$ \\
\hline $\begin{array}{l}\text { Global } \\
\text { Competitiveness } \\
\text { Report (GCR) }\end{array}$ & $\begin{array}{l}\text { World Bank } \\
\text { and the World } \\
\text { Economic } \\
\text { Forum (WEF) }\end{array}$ & $\begin{array}{l}\text { Executive } \\
\text { Opinions on } \\
\text { Institutional } \\
\text { Level Issues (see } \\
\text { Appendix } 1 \text { for } \\
\text { more details) }\end{array}$ & 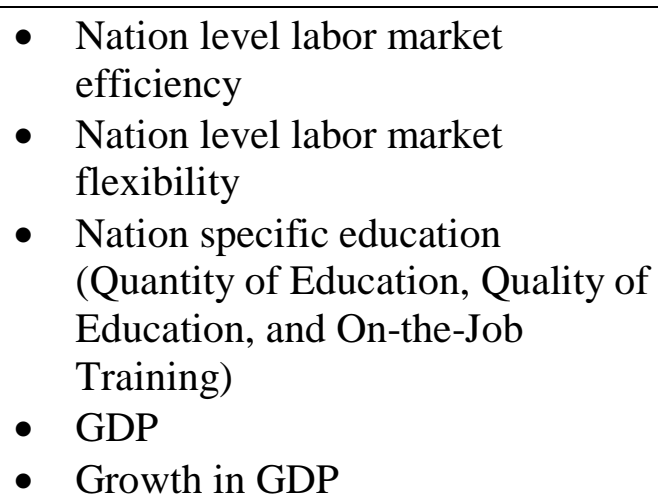 \\
\hline $\begin{array}{l}\text { Worldscope } \\
\text { database }\end{array}$ & & $\begin{array}{l}\text { Company level } \\
\text { performance } \\
\text { data }\end{array}$ & $\begin{array}{l}\text { - Industry (on the two-digit SIC } \\
\text { code level) } \\
\text { - ROA (net income divided by total } \\
\text { assets) } \\
\text { - Firm risk (leverage) }\end{array}$ \\
\hline
\end{tabular}

There are a number of benefits to using the ASSET4 database. First, since many CSR studies use the MCSI KLD data, which we have referenced elsewhere in this study (MCSI, 2019), we felt it appropriate to examine HPWP using a different data set in the present study. Thomson Reuters also offers a strong advantage, from an institutional theory perspective, of more geographically diversified data. Thomson Reuters ASSET4 is a leading provider of objective, comparable, and systematic ESG information covering more than 4,000 firms worldwide, including firms on all major continents. The sample covers over 50 countries, with the majority of the firms from North America (approximately 34\%), Europe (approximately 29\%), and Northeast Asia (approximately 16\%). The remaining $21 \%$ are distributed across the rest of Asia, Africa, and South America. Thomson Reuters ASSET4 covers the leading indices worldwide, including MSCI WORLD, MSCI Europe, STOXX 600, NASDAQ 100, RUSSELL 1000, S\&P 500, FTSE 100, ASX 300, and MSCI Emerging Market. In 2018, Thomson Reuters sold this database, along with assorted other assets, to Refinitv.

The second benefit of ASSET4, since all firms across different stock indices are listed, there is less risk of a sample selection bias on firms actively marketing their social or 
environmental initiatives. This selection bias might appear in databases that focus on firms demonstrating healthy social practices, including HRM, such as Dow Jones Sustainability Index or FTSE4good Index. Third, ASSET4 data are collected using a prescribed catalog of criteria that is identical for all firms inside the database, which allows for better comparisons.

The ESG rating is based on primary data from publicly available sources, including corporate social responsibility (CSR) and annual reports, NGO websites, and stock exchange filings. Data have to go through multiple-step verification and a quality control process (including data entry checks, historical comparisons, and automated quality rules) to ensure an objective, comparable, and transparent database. For each rating, more than 750 data points are aggregated into an equally weighted framework of 250 key performance indicators, which are further grouped into 18 categories within four pillars: social performance, environmental performance, corporate governance performance, and economic performance (Thomson Reuters, 2016). At each level, indicators, categories, pillars, and the overall score are calculated by equally weighting and z-scoring all underlying data points and comparing them with the rest of the firms in the ASSET4 universe. Further description of the dataset as curated by Refinitiv is available online (Refinitv, 2019).

The institutional data derive from two data sources, including the World Bank and the World Economic Forum (WEF). Since 2006, the WEF has released an annual Global Competitiveness Report (GCR) for more than 130 economies worldwide that provides a relatively stable and comparable set of measures for a large number of countries. While there are data prior to the 2006-2007 edition of the GCR, they are not available for this analysis due to changes in the methodology. The WEF based its competitiveness analysis on the Global Competitiveness Index, a highly comprehensive measure for national competitiveness, which captures the microeconomic and macroeconomic foundations of national competitiveness (World Economic Forum, 2015). The different aspects of competitiveness are grouped into 12 pillars that are determinants of national productivity and competitiveness, one of which is labor market efficiency (World Economic Forum, 2015). To measure the different areas of competitiveness, the GCR uses statistical data from internationally recognized agencies such as the International Monetary Fund (IMF); the United Nations Educational, Scientific, and Cultural Organization (UNESCO); and the World Health Organization (WHO). The GCR uses data from the annual WEF Executive Opinion Survey. This survey captures the opinions of business leaders worldwide on a broad range of topics for which international data are scarce, are not available for the global 
set of economies, or require more qualitative assessment. This survey is reviewed and audited regularly by the Gallup Institute.

We draw our firm-specific financial data from the Worldscope database, which contains accounting, financial, and market data from publicly traded firms worldwide. Integrating ASSET4 data with Worldscope and the GCR data, our final sample is an unbalanced panel dataset that includes 20,161 firm-year observations covering a period from 2007-2013.

\section{Measures}

Dependent variable. We followed prior studies (Duque-Grisales \& AguileraCaracuel, 2019; Graafland, 2019; Hull and Rothenberg, 2008) and used return on assets (ROA) as a measure of firm performance. Accounting-based measures reflect a firm's internal efficiency as they reflect the profitability of a firm with respect to the total set of assets under its control (Hull and Rothenberg, 2008). ROA is defined as net income divided by total assets and is derived from Worldscope.

Independent variables. To measure a firm's engagement in HPWP, we identified five scores/variables from Thomson Reuters ASSET4 (Thomson Reuters, 2016). Our HPWP score is calculated by the equally-weighted average of these scores and ranges between 0 to 1, where a higher value indicates a stronger engagement in HPWP. The scores we used are training and development, health and safety, employment quality, diversity and opportunity, and human rights. These include activities and policies to generate a familyfriendly environment; create equal opportunities regardless of gender, age, or ethnicity; avoid layoffs and maintain relations with trade unions; increase the physical and mental health and well-being of all employees, to develop employee skills and competencies; and avoid child or forced labor. Further description of the Thomson Reuters ASSET4 dataset is available online (Thomson Reuters, 2016).

We derived our variables for labor market flexibility and efficiency from the seventh pillar of the annual GCR, details of which can be found in Appendix A. Labor market flexibility captures labor market characteristics in terms of labor-employer relations, flexibility of wage determination, hiring and firing practices, redundancy costs, and national taxation system incentives to work. Labor market efficiency measures characteristics such as the strength of the relationship between the salary and employees' productivity, reliance on professional management, and the ratio of women to men in the labor force. Both scores range between one and seven.

Control Variables. To overcome model misspecifications, we control for firm-, industry-, and nation-specific characteristics that explain firm-level performance by 
including additional control variables. In order to normalize its distribution, firm size is measured by the natural logarithm of the total number of employees. We control for firm risk by using leverage, total debt divided by total assets (Graafland, 2019; Hull \& Rothenberg, 2008). A high level of leverage can limit opportunities to explore new businesses, thereby negatively impacting firm performance. Since the level of education of employees could impact the link between HRM and firm performance, as well as the link between labor market conditions and firm performance, we selected three variables from the GCR to control for the nation-specific level of education and training of employees: Quantity of Education, Quality of Education, and On-the-Job Training from the fifth pillar of the GCR. We also control for GDP, growth in GDP, industry (on the two-digit SIC code level), and year fixed effects in our models.

\section{Empirical Model Specification}

Several considerations guided the development of our empirical model specification. First, given that it was not possible to conduct our study using a controlled experiment, it was important to address such potential econometric issues as endogeneity and reverse causality. For this reason, we lagged all explanatory variables in the model by one year to reduce the likelihood of reverse causality or endogeneity confounding our results, and we included a dummy variable for Year in the model. Second, as is traditional in management research, we developed one model based on only the direct effects (Hypotheses 1, 2, and 4) and a second model that also included indirect effects (Hypotheses 3 and 5). Third, as discussed in the Measures section immediately above, we identified seven continuous control variables to be included in the model and two (including Year) categories of dummy variables. Our empirical model specification is thus:

\section{Direct effects only}

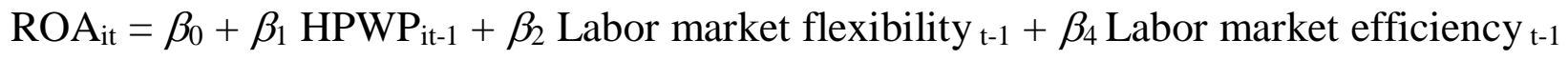
$+\beta_{6}$ Quantity of education $\mathrm{t}_{\mathrm{t}-1}+\beta_{7}$ Quality of education $\mathrm{t}-1+\beta_{8}$ On-the-job training $\mathrm{t}-1+\beta_{9} \log \left(\right.$ Size $\left._{\mathrm{it}-1}\right)+\beta_{10}$ Leverage $_{\mathrm{it}-1}+\beta_{11} \mathrm{GDP}_{\mathrm{t}-1}+\beta_{12}$ GDP annual growth $\mathrm{t}-1+$ $\beta_{13}$ Industry $_{\mathrm{i}}+\beta_{14}$ Year $_{\mathrm{t}-1}$

\section{All effects included}

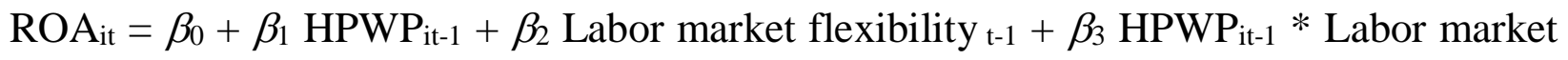
flexibility $\mathrm{t}-1+\beta_{4}$ Labor market efficiency $\mathrm{t}-1+\beta_{5}$ HPWP $_{\mathrm{it}-1} *$ Labor market efficiency $_{\mathrm{t}-1}+\beta_{6}$ Quantity of education $_{\mathrm{t}-1}+\beta_{7}$ Quality of education $\mathrm{t}_{\mathrm{t}-1}+\beta_{8}$ On-the- 
job training $\mathrm{t}-1+\beta_{9} \log \left(\right.$ Size $\left._{\mathrm{it}-1}\right)+\beta_{10}$ Leverage $_{\mathrm{it}-1}+\beta_{11} \mathrm{GDP}_{\mathrm{t}-1}+\beta_{12}$ GDP annual growth $_{\mathrm{t}-1}+\beta_{13}$ Industry $_{\mathrm{i}}+\beta_{14}$ Year $_{\mathrm{t}-1}$

Where $\mathrm{ROA}_{i t}$ refers to the return on assets of company $y_{i}$ in year $\mathrm{t}, \mathrm{HPWP}_{\mathrm{it}-1}$ refers to the high-performance work practices score of companyi in year $\mathrm{t}$, and so on.

\section{ANALYSIS AND RESULTS}

In Table 2, we present descriptive statistics and pairwise correlations for the sample. As expected, some of the institutional variables are highly correlated, e.g., Quality of education and Labor market efficiency (0.75), and On-the-job training and Labor market efficiency (0.78). To prevent the potential threat of multicollinearity issues of the interaction terms, we followed the procedure suggested by Cohen, West, and Aiken (2014). We mean-center the direct terms by subtracting the mean of each variable from the values of each observation.

Table 2. Descriptive statistics and correlation matrix

\begin{tabular}{|c|c|c|c|c|c|c|c|c|c|c|c|c|c|c|c|}
\hline Variable & Mean & S.D. & Min. & Max. & 1 & 2 & 3 & 4 & 5 & 6 & 7 & 8 & 9 & 10 & 11 \\
\hline 1. ROA & 0.04 & 0.12 & -3.59 & 3.36 & 1.00 & & & & & & & & & & \\
\hline 2. HRM & 0.50 & 0.24 & 0.07 & 0.98 & $0.05^{* *} *$ & 1.00 & & & & & & & & & \\
\hline $\begin{array}{l}\text { 3. Labor } \\
\text { market } \\
\text { flexibility }\end{array}$ & 5.08 & 0.71 & 3.36 & 6.39 & $0.02 * *$ & $-0.21 * *$ & 1.00 & & & & & & & & \\
\hline $\begin{array}{l}\text { 4. Labor } \\
\text { market } \\
\text { efficiency }\end{array}$ & 5.11 & 0.53 & 2.48 & 5.88 & 0.01 & $-0.10^{* *}$ & $0.74 * *$ & 1.00 & & & & & & & \\
\hline $\begin{array}{l}\text { 5. Quantity of } \\
\text { education }\end{array}$ & 5.68 & 0.78 & 2.70 & 7.00 & $-0.06^{* *}$ & $0.03 * *$ & $0.19 * *$ & $0.42 * *$ & 1.00 & & & & & & \\
\hline $\begin{array}{l}\text { 6. Quality of } \\
\text { education }\end{array}$ & 5.02 & 0.58 & 2.57 & 6.17 & 0.00 & $-0.05^{* *}$ & $0.54 * *$ & $0.75 * *$ & $0.36 * *$ & 1.00 & & & & & \\
\hline $\begin{array}{l}\text { 7. On-the-job } \\
\text { training }\end{array}$ & 5.24 & 0.52 & 3.37 & 6.04 & -0.01 & $-0.04 * *$ & $0.59 * *$ & $0.78 * *$ & $0.35^{* *}$ & $0.65 * *$ & 1.00 & & & & \\
\hline 8. Size & 15.77 & 1.68 & 9.63 & 22.05 & $-0.09 * *$ & $0.38 * *$ & $-0.10 * *$ & $-0.08 * *$ & $-0.05 * *$ & $-0.11 * *$ & $-0.03 * *$ & 1.00 & & & \\
\hline 9. Leverage & 0.25 & 0.19 & 0.00 & 2.67 & $-0.08^{* *}$ & $0.03 * *$ & $-0.05 * *$ & $-0.03 * *$ & $0.05^{* *}$ & $-0.03 * *$ & $-0.04 * *$ & $0.12 * *$ & 1.00 & & \\
\hline $\begin{array}{l}\text { 10. GDP } \\
\text { absolute } \\
\text { (billions) }\end{array}$ & 5760 & 5890 & 19.9 & 16200 & $0.04 * *$ & $-0.08^{* *}$ & $-0.14 * *$ & $-0.14 * *$ & $-0.24 * *$ & $-0.05^{* *}$ & $-0.27 * *$ & -0.01 & $-0.04 * *$ & 1.00 & \\
\hline $\begin{array}{l}\text { 1. GDP annual } \\
\text { growth }\end{array}$ & 1.75 & 3.11 & -8.86 & 17.66 & 0.01 & -0.11 ** & $0.50 * *$ & $0.54 * *$ & $0.39 * *$ & $0.12 * *$ & $0.38 * *$ & $0.08 * *$ & $0.04 * *$ & $-0.13 * *$ & 1.00 \\
\hline
\end{tabular}

We tested for multicollinearity by a generalized variance inflation factor (VIF). VIFs measure the impact of multicollinearity on the variance of the regression coefficient 
of an explanatory variable. The highest VIF statistic for our data is well below the recommended maximum value of 10 (Neter et al., 1996; Shieh, 2010). We concluded that multicollinearity is not an issue for our further analysis.

Table 3 presents the results of the regression models. We used pooled OLS regression models with robust standard errors, clustered at the firm level. All explanatory variables are lagged by one year to avoid endogeneity problems since the reverse causality between HPWP and ROA is possible.

Model 2 introduces our variables of interest. Consistent with prior work (c.f., Combs et al., 2006), we find a significant $(\mathrm{p}<0.01)$ positive link between HPWP and firm performance. Hypothesis 1 is thus supported. Labor market flexibility is not shown to be significant ( $p>0.10$ ), and the coefficient is almost zero, indicating lack of support for Hypothesis 2. Our results also indicate that labor market efficiency is positively and significantly $(\mathrm{p}<0.01)$ associated with firm performance, supporting Hypothesis 4.

We introduce the interactions in Model 3. The results support or partially support our hypotheses. Labor market flexibility does appear to be significant $(\mathrm{p}<0.05)$ in the hypothesized direction in Model 3. Again, it is not significant when the interaction effects are not included. The interaction of HPWP with labor market flexibility has a negative coefficient $(\mathrm{p}<0.05)$, indicating that, as predicted in Hypothesis 3, HPWP has a more positive effect on firm performance in countries with less labor market flexibility. In nations with strong formal institutions - low labor market flexibility - a stable formal institutional framework limits top management teams' ability to make the more unwise adhoc decisions that they might otherwise make. As a result, adoption of HPWP is more likely to entail the complete "bundle" that engages employees and has been found to be more financially beneficial (Asmawi \& Chew, 2016; Combs et al., 2006; Schneider et al., 2018). Our findings could indicate that HPWP stands out more to internal and external stakeholders in markets with less labor market flexibility, providing reputational benefits that are harder to achieve in settings where such practices are normal (c.f., Su, Peng, Tan, \& Cheung, 2016).

Finally, the coefficient of the interaction of HPWP and labor market efficiency is positive $(\mathrm{p}<0.01)$, indicating that, as predicted in Hypothesis 5, HPWP more positively affects firm performance in countries with a more labor market efficiency.

Our results support Hypotheses 1, 3, 4, and 5. 
Table 3. Results of OLS regression (dependent variable: ROA)

\begin{tabular}{|c|c|c|c|}
\hline Variable & Model 1 & Model 2 & Model 3 \\
\hline HPWP & & $\begin{array}{l}0.053 * * * \\
(0.006)\end{array}$ & $\begin{array}{l}0.054 * * * \\
(0.006)\end{array}$ \\
\hline HPWP*Labor market flexibility & & & $\begin{array}{l}-0.022 * * \\
(0.009)\end{array}$ \\
\hline HPWP* Labor market efficiency & & & $\begin{array}{l}0.039 * * * \\
(0.011)\end{array}$ \\
\hline Labor market flexibility & & $\begin{array}{l}0.003 \\
(0.002)\end{array}$ & $\begin{array}{l}0.054 * * \\
(0.002)\end{array}$ \\
\hline Labor market efficiency & & $\begin{array}{l}0.015^{* * *} * \\
(0.005)\end{array}$ & $\begin{array}{l}0.015 * * * \\
(0.005)\end{array}$ \\
\hline Quantity of education & $\begin{array}{c}-0.008 * * * \\
(-0.002)\end{array}$ & $\begin{array}{l}-0.009 * * * \\
(0.002)\end{array}$ & $\begin{array}{l}-0.009 * * * \\
(0.002)\end{array}$ \\
\hline Quality of education & $\begin{array}{l}0.009 * * * \\
(0.003)\end{array}$ & $\begin{array}{l}0.001 \\
(0.004)\end{array}$ & $\begin{array}{l}0.001 \\
(0.004\end{array}$ \\
\hline On-the-job training & $\begin{array}{c}-0.017 * * * \\
(0.004)\end{array}$ & $\begin{array}{l}-0.023 * * * \\
(0.004)\end{array}$ & $\begin{array}{l}-0.007 * * * \\
(0.004)\end{array}$ \\
\hline Size & $\begin{array}{l}-0.003 * \\
(0.002)\end{array}$ & $\begin{array}{l}-0.007 * * * \\
(0.002)\end{array}$ & $\begin{array}{l}-0.007 * * * \\
(0.002)\end{array}$ \\
\hline Leverage & $\begin{array}{l}-0.054 * * * \\
(0.015)\end{array}$ & $\begin{array}{l}-0.052 * * * \\
(0.015)\end{array}$ & $\begin{array}{l}0.051 * * * \\
(0.015)\end{array}$ \\
\hline $\begin{array}{c}\text { GDP absolute } \\
\text { p value }\end{array}$ & $\begin{array}{l}0.000 * * * \\
(0.000\end{array}$ & $\begin{array}{l}0.000 * * \\
(0.000\end{array}$ & $\begin{array}{l}0.000 * * \\
(0.000\end{array}$ \\
\hline GDP annual growth & $\begin{array}{l}0.001 * * * \\
(0.000)\end{array}$ & $\begin{array}{l}0.002 * * * \\
(0.000)\end{array}$ & $\begin{array}{l}0.002 * * * \\
(0.000)\end{array}$ \\
\hline Constant & $\begin{array}{l}0.157 * * * \\
(0.029)\end{array}$ & $\begin{array}{l}0.178 * * * \\
(0.031)\end{array}$ & $\begin{array}{l}0.189 * * * \\
(0.031)\end{array}$ \\
\hline Industry dummies included & YES & YES & YES \\
\hline Year dummies included & YES & YES & YES \\
\hline Adj. R2 & 0.068 & 0.081 & 0.081 \\
\hline Obs. per group (min/avg/max): & $1 / 5.3 / 7$ & $1 / 5.3 / 7$ & $1 / 5.3 / 7$ \\
\hline Number of observations & 20161 & 20161 & 20161 \\
\hline
\end{tabular}

$* * * \mathrm{p}<0.01 ; * * \mathrm{p}<0.05 ; * \mathrm{p}<0.1$ All significance tests are two-tailed.

\section{DISCUSSION AND CONCLUSION}

We not only does HPWP drive financial performance, but it does so in a sample that extends across an extensive global sample of companies and in a variety of institutional settings beyond - but including - the traditional North American and European settings, as has been called for recently in this journal (Luxmore \& Hull, 2018) on the grounds that 
institutional pressures exist in developed and developing nations alike. The literature has already taken notice of the importance of context and that it is unwise to assume that concepts such as HPWP that were derived in developed nations are universally applicable (Cooke, 2018). Given HPWP's beneficial effects, we conclude that companies seeking the best financial returns possible should, generally, at least consider engaging in HWPW.

Hypothesis 2 that labor market flexibility is positively associated with firm performance was not supported, except when labor market flexibility's interaction with HPWP was included in the model, as predicted in Hypothesis 3. Thus, we found support for our Hypothesis 3, that HPWP more positively affects financial performance in settings of low labor market flexibility. We have argued that the more formal institutional pressures help ensure that more successful "bundles" of work practices are adopted, rather than individual practices being adopted piecemeal, leading to higher benefit from these practices (Asmawi \& Chew, 2016; Combs et al., 2006; Huselid, 1995). Similar to what was found by Ahmed et al. (2016), this indicates that the freedom from formal regulation that companies might covet might not benefit all companies. The legal requirements that push companies toward HPWP as a standard practice allow them to adopt a complete, profitable bundle of HPWP (Asmawi \& Chew, 2016; Combs et al., 2006; Huselid, 1995). While it may seem odd, or even counterintuitive, to suggest in a management journal that businesses will benefit from more government oversight, our findings suggest that, at least with respect to HPWP, more regulation increases the value of HPWP.

Hypothesis 4 is supported as well, meaning that labor market efficiency is good for business and profits. It indicates that informal institutional pressures to treat employees well, train them, and reward them for excellent performance helps businesses succeed. As with labor market flexibility, a question to be addressed in future research is whether this effect increases with consistent labor market efficiency over time, or whether the effect is tied only to the current level of labor market efficiency. Lastly, support for Hypothesis 5 indicates that labor market efficiency and HPWP go well together from a financial perspective. The pool of available workers is deeper because artificial limits (e.g., pressures keeping talented women from working) are not in place, and the workers in this institutional context are familiar with and appreciate the beneficial aspects of HPWP. Thus, while all companies benefit financially from labor market efficiency, companies that are strong on HPWP will benefit more because they will attract top employees from a pool that includes women and other candidates who might not be able to apply in other settings. Besides, informal institutional pressures for HPWP may lead to a greater appreciation of those companies that undertake them, and thus increase reputational impact of HPWP (c.f., Deephouse et al., 2016). While our data do not address this directly, it seems almost 
syllogistically clear that it is profitable to encourage increased women's rights and otherwise promote cultural expectations that encourage participation in and appreciation of HWPW; the elements of HPWP that focus on hiring and promoting the ablest employees will work best in cultures where the smartest and most talented workers are not barred from seeking work by informal institutional pressure.

Overall, our findings that the positive effect of HPWP on firm financial performance is more pronounced in settings of high labor market efficiency and low labor market flexibility indicates that context does, as Cooke (2018) points out eloquently, matter. One conclusion we can draw from these results is that measuring institutional pressure using non-categorical variables tied to informality and formality yields significant results. This conclusion is consistent with the theoretical case for such an approach, that the actual institutional conditions in existence at the time of the study are what should be measured rather than antecedents, such as the legal traditions that were in place when the country was formed (Wood \& Brewster, 2016). This contribution is more likely to be of interest to institutional theorists than it is to CSR researchers.

This study also contributes to our understanding of how both informal and formal institutions have different impacts on the value extracted from HPWP. Informal institutions focus on the norms of society, and the business itself. Our findings highlight the importance of informal institutions in the context of understanding labor relations, high-performance work practices, and financial performance. We suggest that informal institutional pressures impact the reputational impact of HPWP, which in turn affects recruitment, employee effectiveness, and financial performance (Su et al., 2016; Tang et al., 2012). On the other hand, formal institutional pressures are more likely to impact the behavior and performance of firms more directly. In this case, we hypothesized and found some support for the idea that formal institutional pressures encouraged firms to undertake a more comprehensive set of human resource practices, maximizing the complementarities among them, and thus the benefit that could be attained from them. These findings contribute to the research on the role of institutional pressures on HPWP, as well as the call for more focus on the difference between information and formal institutional pressures.

One limitation of our study is, though we do have and include data from Africa and South America, our data are still weighted towards North America, Europe, and Asia. Institutional theory has been extensively applied to explain activity in developing nations and how it differed from activity in developed nations where, in theory, institutions had reached such a level of efficiency that they were effectively invisible (Peng, 2003, 2014). The institutional effects of developing nations in other parts of the world, such as Africa, on the SHRM-financial performance relationship deserve further study. A second 
limitation of this study is that the model only accounts for $7 \%-8 \%$ of the variance in the dependent variable. Future studies should attempt to build a model with stronger explanatory power.

Another limitation is that we treat HPWP as one variable. However, it may be that different types of work practices contribute to performance in different ways, and the moderating effect of institutional context may differ for different bundles as well. Returning to the literature focused on the bundling of different aspects of HPWP to find the best possible fit (Asmawi \& Chew, 2016; Combs et al., 2006), we suggest that, consistent with Huselid's (1995) seminal position, the best fit will involve an alignment of internal and external factors.

The findings point to some areas for future research. First, future research into which sorts and combinations of formal institutional pressures yield the highest financial rewards for HPWP is called for, and the results are likely to be of interest to policymakers as well as business leaders. In the same vein, looking at different measures and aspects of the institutional environment would be of use. There is also an opportunity to evaluate specific bundles of HPWP in firms of specific nations (e.g., Asmawi \& Chew, 2016; Williams \& Lee, 2016) or across many nations, so as to better understand how our findings interact with those of the HPWP bundling literature. More detailed metrics of HPWP can also help parse out the impact of combinations of work practices. Another area for future work is to explore similar relationships for different workforces. For example, our findings with respect to labor market flexibility are not entirely consistent with Chacar et al. (2010)'s finding with respect to unskilled labor market flexibility. Their findings suggest that unskilled labor market flexibility helps firm performance, while we found that labor market flexibility never helps and sometimes hurts profits. Although Chacar et al. (2010)'s measure of labor market flexibility is more narrow than ours, the difference in findings underscores the need for further research that takes a more fine-grained approach to the concepts at hand. Exploring how labor market flexibility's effects vary across different ratios of unskilled to skilled workers, for example, is one potential direction for future research.

The implications for CSR research are also noteworthy, particularly if future work indicates that our findings with respect to HPWP are generalizable to other dimensions of CSR: The degree of government regulation does seem to affect the strength of the CSRfinancial performance relationship, but not its overall direction. Likewise, a culture that values CSR will, at least with respect to HPWP, appreciate it and reward it more than a culture that does not. We cannot draw conclusions from these findings regarding government regulation and financial performance in other areas of CSR, but suggest that 
such beneficial regulations might be found in areas such as sustainability. Further study in these and similar contexts would be helpful.

The research has practical implications for policymakers. Since labor market efficiency improves firm performance, policy changes that encourage labor market efficiency and HPWP would be particularly effective at stimulating profitability. For example, governments that want to stimulate their economies should enact laws and regulations that formally discourage sexism and nepotism; they should also seek out ways to informally discourage these practices. We note, however, that changing informal uncodified institutional pressures is, by definition and empirical demonstration, more difficult to legislate than changing codified, formal laws and regulations and is fraught with the danger of unexpected and negative consequences (Williamson, 2009). Thus, such efforts should be pursued with caution, if at all, and further research into how to successfully increase a nation's labor market efficiency is needed.

A practical implication for practitioners is that efforts spent lobbying against minimum wage laws and labor protection laws may be more profitably spent lobbying for conditions that encourage equal market participation by women, racial minorities, the deaf and disabled, homosexuals, and so on. While businesses will differ in how much value they would extract from this activity, our findings suggest that overall all would benefit. In such an economy, profits for companies that engage successfully in HPWP are higher yet. We note that this finding aligns with those of Witt and Jackson (2016), in that they did not find the expected benefits of a liberal market economy either. Our reasoning here may also help explain their findings.

Overall, firms and governments should pay attention to informal institutions, which are difficult to adjust through direct government legislation (Williamson, 2009). Companies can do this by leading the way with their own policies and shifting cultural expectations with their own workers first, and expanding outward from there (c.f., Tang et al., 2012). Promoting their own initiatives to the public might thus, in addition to whatever reputational benefits might accrue, help normalize the company's HRM practices, increasing informal institutional support for the practices and thus their profitability. This interplay between CSR best practices and informal institutional pressure deserves more study than it has received thus far. We hope the current study contributes to filling this gap.

\section{REFERENCES}

Ahmed, E., D’Netto, B., Chelliah, J., \& Fein, E. (2016). Psychological contract breach: Consequences of unkept promises of permanent employment. Contemporary Management Research, 12(2), 183-212. https://doi.org/10.7903/cmr.13914 
Asmawi, A., \& Chew, K. W. (2016). High performance work practices (HPWP) in Malaysian R\&D organizations. Journal of Advanced Management Science, 4(6), 467-470. https://doi.org/10.18178/joams.4.6.467-470

Barney, J. B. (1986). Organizational culture: Can it be a source of sustained competitive advantage? Academy of management review, 11(3), 656-665. https://doi.org/10.5465/amr.1986.4306261

Barney, J. (1991). Firm resources and sustained competitive advantage. Journal of Management, 17(1), 99-120. https://doi.org/10.1177/014920639101700108

Barney, J. B. (2001). Is the resource-based "view" a useful perspective for strategic management research? Yes. Academy of Management Review, 26(1), 41-56. https://doi.org/10.5465/amr.2001.4011938

Barney, J. B. (2018). Why resource-based theory's model of profit appropriation must incorporate a stakeholder perspective. Strategic Management Journal, 39(13), 3305-3325. https://doi.org/10.1002/smj.2949

Bauer, F., Schriber, S., Degischer, D., \& King, D. R. (2018). Contextualizing speed and cross-border acquisition performance: Labor market flexibility and efficiency effects. Journal of World Business, 53(2), 290-301.

https://doi.org/10.1016/j.jwb.2018.01.001

Caligiuri, P. (2014). Many moving parts: Factors influencing the effectiveness of HRM practices designed to improve knowledge transfer within MNCs. Journal of International Business Studies, 45(1), 63-72. https://doi.org/10.1057/jibs.2013.52

Chacar, A., Newburry, W., \& Vissa, B. (2010). Bringing institutions into performance persistence research: Exploring the impact of product, financial, and labor market institutions. Journal of International Business Studies, 41(7), 1119-1140. https://doi.org/10.1057/jibs.2010.3

Cohen, P., West, S. G., \& Aiken, L. S. (2014). Applied Multiple Regression/Correlation Analysis for the Behavioral Sciences. Psychology Press.

Cooke, F. L. (2018). Concepts, contexts, and mindsets: Putting human resource management research in perspectives. Human Resource Management Journal, 28(1), 1-13. https://doi.org/10.1111/1748-8583.12163

Costa, C., Lages, L. F., \& Hortinha, P. (2015). The bright and dark side of CSR in export markets: Its impact on innovation and performance. International Business Review, 24(5), 749-757. https://doi.org/10.1016/j.ibusrev.2015.01.008

Cole, M. S., Bernerth, J. B., Walter, F. \& Holt, D. T. (2010). Organizational justice and individuals' withdrawal: Unlocking the influence of emotional exhaustion. Journal of Management Studies, 47(3), 367-390. 
https://doi.org/10.1111/j.1467-6486.2009.00864.x

Combs, J., Liu, Y., Hall, A., \& Ketchen, D. (2006). How much do high-performance work practices matter? A meta-analysis of their effects on organizational performance. Personnel Psychology, 59(3), 501-528. https://doi.org/10.1111/j.1744-6570.2006.00045.x

Deephouse, D. L., Newburry, W., \& Soleimani, A. (2016). The effects of institutional development and national culture on cross-national differences in corporate reputation. Journal of World Business, 51(3), 463-473.

https://doi.org/10.1016/j.jwb.2015.12.005

Duque-Grisales, E., \& Aguilera-Caracuel, J. (2019). Environmental, Social and Governance (ESG) Scores and Financial Performance of Multilatinas: Moderating Effects of Geographic International Diversification and Financial Slack. Journal of Business Ethics, 2019, May. https://doi.org/10.1007/s10551-019-04177-w

El Akremi, A., Gond, J. P., Swaen, V., De Roeck, K., \& Igalens, J. (2018). How do employees perceive corporate responsibility? Development and validation of a multidimensional corporate stakeholder responsibility scale. Journal of Management, 44(2), 619-657. https://doi.org/10.1177/0149206315569311

Fey, C. F., Morgulis-Yakushev, S., Jeong Park, H. \& Björkman, I. (2009). Opening the black box of the relationship between HRM practices and firm performance: A comparison of MNE subsidiaries in the USA, Finland, and Russia. Journal of International Business Studies, 40(4), 690-712.

https://doi.org/10.1057/jibs.2008.83

Gilman, M., \& Raby, S. (2013). National context as a predictor of high-performance work system effectiveness in small-to-medium-sized enterprises (SMEs): A UK-French comparative analysis. International Journal of Human Resource Management, 24(2), 372-390. https://doi.org/10.1080/09585192.2012.672447

Ghoul, S., Guedhami, O. \& Kim, Y. J. (2017). Country-level institutions, firm value, and the role of corporate social responsibility initiatives. Journal of International Business Studies, 48, 360-375. https://doi.org/10.1057/jibs.2016.4

Graafland, J. (2019). Economic freedom and corporate environmental responsibility: The role of small government and freedom from government regulation. Journal of Cleaner Production, 218, 250-258. https://doi.org/10.1016/j.jclepro.2019.01.308

Guerci, M., Decramer, A., Van Waeyenberg, T., \& Aust, I. (2019). Moving Beyond the Link Between HRM and Economic Performance: A Study on the Individual Reactions of HR Managers and Professionals to Sustainable HRM. Journal of Business Ethics, 160, 783-800. https://doi.org/10.1007/s10551-018-3879-1 
Hall, P. A. (2015). Varieties of capitalism. Emerging Trends in the Social and Behavioral Sciences: An Interdisciplinary, Searchable, and Linkable Resource, 1-15. Wiley \& Sons, New York.

Helmig, B., Spraul, K., \& Ingenhoff, D. (2016). Under positive pressure: How stakeholder pressure affects corporate social responsibility implementation. Business \& Society, 55(2), 151-187. https://doi.org/10.1177/0007650313477841

Hull, C. E., \& Rothenberg, S. (2008). Firm performance: The interactions of corporate social performance with innovation and industry differentiation. Strategic Management Journal, 29(7), 781-789. https://doi.org/10.1002/smj.675

Huselid, M. (1995). The impact of human resource management practices on turnover, productivity, and corporate financial performance, Academy of Management Journal, 38(3), 635-672. https://doi.org/10.5465/256741

Ibrahim, N. A. F. (2017). The relationship between corporate social responsibility and employer attractiveness in Egypt: The moderating effect of the individual's income. Contemporary Management Research, 13(2), 81-106.

https://doi.org/10.7903/cmr.17430

Ioannou, I., \& Serafeim, G. (2012). What drives corporate social performance? The role of nation-level institutions. Journal of International Business Studies, 43, 834-864. https://doi.org/10.1057/jibs.2012.26

Luxmore, S. R., \& Hull, C. E. (2018). How formal and informal institutional environments affect the way Greenpeace fights genetically-modified organisms in Europe and the United States. Contemporary Management Research, 14(3), 225-252. https://doi.org/10.7903/cmr.17889

Luxmore, S. R., Hull, C. E., \& Tang, Z. (2018). Institutional determinants of environmental corporate social responsibility: Are multinational entities taking advantage of weak environmental enforcement in lower-income nations? Business and Society Review, 123(1), 151-179. https://doi.org/10.1111/basr.12138

Maamari, B. E., \& Alameh, K. (2016). Talent management moderating the relationship between recruitment for the highly skilled and HR policies. Contemporary Management Research, 12(1), 121-138. https://doi.org/10.7903/cmr.14133

Mallon, M. R., \& Fainshmidt, S. (2017). Assets of foreignness: a theoretical integration and agenda for future research. Journal of International Management, 23(1), 4355. https://doi.org/10.1016/j.intman.2016.08.001

MCSI. (2019). What Do We Measure? MCSI ESG Ratings Index. Retrieved from https://www.msci.com/esg-ratings\#p_p_id_com_liferay_journal_content_web_ 
portlet_JournalContentPortlet_INSTANCE_0Gi5FRajcFgm_Accessed Aug. 17, 2019.

Minbaeva, D., Pedersen, T., Björkman, I., Fey, C. F., \& Park, H. J. (2014). Retrospective: MNC knowledge transfer, subsidiary absorptive capacity, and HRM. Journal of International Business Studies, 45(1), 38-51. https://doi.org/10.1057/jibs.2013.43

Neter, J., Kutner, M. H., Nachtsheim, C. J., \& Wasserman, W. (1996). Applied Linear Statistical Models ( $4^{\text {th }}$ ed.). Chicago: Irwin.

Obeidat, S. M., Mitchell, R., \& Bray, M. (2016). The link between high performance work practices and organizational performance: Empirically validating the conceptualization of HPWP according to the AMO model. Employee Relations, 38(4), 578-595. https://doi.org/10.1108/er-08-2015-0163

Paauwe, J. (2009). HRM and performance: Achievements, methodological issues and prospects. Journal of Management Studies, 46(1), 129-142. https://doi.org/10.1111/j.1467-6486.2008.00809.x

Paauwe, J., \& Boon, C. (2018). Strategic HRM: A critical review. In Human Resource Management, 49-73. Routledge.

Paauwe, J., \& Boselie, P. (2003). Challenging 'strategic HRM' and the relevance of the institutional setting. Human Resource Management Journal, 13(3), 56-70. https://doi.org/10.1111/j.1748-8583.2003.tb00098.x

Peng, M. W. (2003). Institutional transitions and strategic choices. Academy of Management Review, 28(2), 275-296. https://doi.org/10.2307/30040713

Peng, M. W. (2014). New research directions in the institution-based view. Multidisciplinary insights from new AIB fellows, Research in Global Strategic Management, 16, 59-78. https://doi.org/10.1108/s1064-485720140000016002

Refinitiv. (2019). ESG data and solutions from Refinitiv. Retrieved from https://www.refinitiv.com/content/dam/marketing/en_us/documents/brochures/es g-research-brochure.pdf

Rothenberg, S., Hull, C. E., \& Tang, Z. (2017). The impact of human resource management on corporate social performance strengths and concerns. Business \& Society, 56(3), 391-418. https://doi.org/10.1177/0007650315586594

Scott, W. R. (2013). Institutions and Organizations: Ideas, Interests, and Identities. Sage Publications.

Schneider, B., Yost, A. B., Kropp, A., Kind, C., \& Lam, H. (2018). Workforce engagement: What it is, what drives it, and why it matters for organizational performance. Journal of Organizational Behavior, 39(4), 462-480. https://doi.org/10.1002/job.2244 
Shieh, G. (2010). On the misconception of multicollinearity in detection of moderating effects: Multicollinearity is not always detrimental. Multivariate Behavioral Research, 45(3), 483-507. https://doi.org/10.1080/00273171.2010.483393

Simon, H. A. (2013). Administrative Behavior. Simon and Schuster, New York.

Sondermann, D. (2018). Towards more resilient economies: the role of well-functioning economic structures. Journal of Policy Modeling, 40(1), 97-117. https://doi.org/10.1016/j.jpolmod.2018.01.002

Storey, J., Ulrich, D., \& Wright, P. M. (2019). Strategic Human Resource Management: A Research Overview. Routledge, Philadelphia.

Su, W., Peng, M.W., Tan, W., \& Cheung, Y.-L. (2016). The signaling effect of corporate social responsibility in emerging economies. Journal of Business Ethics, 134(3), 479-491. https://doi.org/10.1007/s10551-014-2404-4

Sun, L. Y., Aryee, S., \& Law, K. S. (2007). High-performance human resource practices, citizenship behavior, and organizational performance: A relational perspective. Academy of Management Journal, 50(3), 558-577. https://doi.org/10.5465/amj.2007.25525821

Swoboda, B., Puchert, C., \& Morschett, D. (2016). Explaining the differing effects of corporate reputation across nations: a multilevel analysis. Journal of the Academy of Marketing Science, 44(4), 454-473.

https://doi.org/10.1007/s11747-015-0457-2

Tang, Z., Hull, C. E., \& Rothenberg, S. (2012). How corporate social responsibility engagement strategy moderates the CSR-financial performance relationship. Journal of Management Studies, 49(7), 1274-1303. https://doi.org/10.1111/j.1467-6486.2012.01068.x

Tang, Z., \& Hull, C. (2012). An investigation of entrepreneurial orientation, perceived environmental hostility, and strategy application among Chinese SMEs. Journal of Small Business Management, 50(1), 132-158. https://doi.org/10.1111/j.1540-627x.2011.00347.x

Thomson Reuters. (2016). ASSET 4 dataset. Retrieved from http://extranet.datastream.com/data/ASSET4\%20ESG/Index.htm.

Weng, D. H., \& Peng, M. W. (2018). Home bitter home: How labor protection influences firm offshoring. Journal of World Business, 53(5), 632-640. https://doi.org/10.1016/j.jwb.2018.03.007

Williams, C., \& Lee, S. H. (2016). Knowledge flows in the emerging market MNC: The role of subsidiary HRM practices in Korean MNCs. International Business Review, 25(1), 233-243. https://doi.org/10.1016/j.ibusrev.2014.08.011 
Williamson, C. R. (2009). Informal institutions rule: institutional arrangements and economic performance. Public Choice, 139(3-4), 371-387. https://doi.org/10.1007/s11127-009-9399-x

Witt, M. A., \& Jackson, G. (2016). Varieties of Capitalism and institutional comparative advantage: A test and reinterpretation. Journal of International Business Studies, 47(7), 778-806. https://doi.org/10.1057/s41267-016-0001-8

Wood, G., \& Brewster, C. (2016). Corporate governance and human resource management. Annals of Corporate Governance, 1(4), 249-319. https://doi.org/10.1561/109.00000010

World Economic Forum. (2015). World Economic Forum's Global Competitiveness Report, 2014-2015. Retrieved from http://reports.weforum.org/globalcompetitiveness-report-2014-2015/

Yang, Y., Orzes, G., Jia, F., \& Chen, L. (2019). Does GRI Sustainability Reporting Pay Off? An Empirical Investigation of Publicly Listed Firms in China. Business \& Society, Feb, 1-35. https://doi.org/10.1177/0007650319831632.

Zhang, M., Di Fan, D., \& Zhu, C. J. (2014). High-performance work systems, corporate social performance and employee outcomes: Exploring the missing links. Journal of Business Ethics, 120(3), 423-435. https://doi.org/10.1007/s10551-013-1672-8

Pro. Clyde Eirikur Hull (Corresponding author) holds the rank of Professor in the Department of Management in the Saunders College of Business at RIT. He has published in Strategic Management Journal, Journal of Management Studies, and Resources, Conservation and Recycling, among others.

Pro. Sandra Rothenberg holds the rank of Professor in the Department of Management in the Saunders College of Business at RIT. She is also Department Chair of the Department of Public Policy in the College of Liberal Arts at RIT. She has published in Strategic Management Journal, Production and Operations Management, and Journal of Management Studies, among others.

Dr. Sebastian Vogt earned his Doctorate in Business Management at Würzburg University. He has worked for Deloitte, where he holds the rank of Manager, in technology and management consulting since graduation. 